\title{
0. Outline of the Argument, Basic Hypotheses, and Remarks on Methodology
}

"Our philological home is the earth: it can no longer be the nation."

(Erich Auerbach, "Philology and Weltliteratur" [1952/1969])

0.-This book has two main objectives, one theoretical, the other historical. In terms of theory, it tries to explore the metaphor of culture as originating from processes of transfer and extraction evolving within a virtual network. In this respect, it is inspired by technological developments that were and go on taking place in the period of its conception. But the theoretical concept here submitted is not systematically linked to such recent trends of technological evolution.

This feature shall become evident in a second part which will investigate the productivity of this new approach to conceptualizing culture by targeting a specific field of cultural production from the pre-technological era: literary texts, specifically dramatic texts, mainly "Western", from the early modern age. The choice of the period was, at least in part, driven by the intention to keep the present-day context of inspiration to which the general theoretical concept is linked strictly separate from the theoretical claims that may be derived from the investigation of a specific section of the literary field. By way of discussing a range of concrete examples of processes of cultural transfer and exchange, the second section of this book shall also help elucidate facets and implications of the theoretical approach presented in the first section that may otherwise remain all too abstract. In addition, this part on early modern drama as mass media has the ambition to provide a portrait of the literary text corpus in question that might yield new historical insights for scholars working in that specific field. It is thus intended to demonstrate that the new approach submitted here may be valid and valuable beyond the limits of theoretical speculation.

In a third part, I will present succinct case studies which are apt to cast a light on specific problems of a network theory of cultural production and reception that require a more detailed reflection. As the claim linked to the theoretical approach suggested in this book is a more general one, there will be passages in which I shall deal with texts from other genres and periods (e.g. the nineteenth-century realist novel) in order to further develop the implications of the main theoretical ideas. - In this last major section, I will also address at some length the approach to conceptualizing cultural production and reception which is opposite to mine, namely the assumption of the existence of "national 
literatures", including the derivatives of this latter concept, up to postcolonial theory.-A brief concluding part will attempt to highlight some problems involved in my theorizing that might lead to further scholarly discussions.

There is a characteristic regarding methodology I should already like to formulate at this point: A book is, by necessity, a linear structure. According to the tradition of scholarship as established in this part of the world since Aristotle's Rhetoric at the latest, it is to follow, in addition, a hierarchical order (from more abstract to concrete, or vice versa). Against this backdrop, it would be far too ambitious to consistently try to demonstrate my main thesis-that network structures are a very useful model for conceiving of how cultural production works-in the structuring of the present study. That said, I have attempted to bring content and form closer together in this volume than was my practice in previous books. Accordingly, there will be much more cross-references to be found in the following pages than is usually the case in scholarly publications. In addition, I will repeatedly address, in simulation of "recursive structures", identical abstract topics under varying aspects and in different parts of this book. And, finally, the chapters of the more theoretical Part I, as well as the ones of Parts II and III, will be characterized by a string-like and additive structure, rather than by a structure of (supposed) causal or "logical" order, as is traditionally the case in scholarship.

There is not only an "aesthetic", but also a rhetorical element involved in my decision to present this book according to the structuring just outlined. In my discussions with the junior researchers of the DramaNet team, as well as in my readings of their books and papers, I believe to have realized that such a decentered structure might be more appropriate, at this moment of cultural and scholarly history, for presenting an argument than what would result from a routine application of the traditional principles, all the more as the practice of reading, including "serious" reading, has changed dramatically over the last decades: from integral to interruptive, from focused to dispersed. From the perspective of a book that tries to take advantage, at least by way of converting it into a useful metaphorical resource, of the "agent" of these transformations, the Internet, it would be somewhat self-contradictory to lament these processes as phenomena of decadence and to try fighting against them.

This introductory chapter seeks to give a concise overview of the book's argument in its entirety. The theoretical frame that is meant to be challenged by the attempt at conceptualizing a network theory of cultural production is, as already hinted at, the concept of "national literatures", in the sense that the concrete language in which a literary text is written is not regarded as subordi- 
nate, but as the primary characteristic of the text in question; all relevant discussion in this respect shall be relegated to a separate chapter in Part III of this book. In this introduction, I will limit my remarks as to existing theoretical framings of cultural production to some critical points with regard to approaches that are in principle close to my perspective, that is, that may qualify as "post-Romantic", in the sense that they intentionally go beyond the deeply rooted notion of cultural production as a sort of godlike creation, as being based on rationally inexplicable parameters commonly labelled "inspiration" or "ingenuity".

1.-It was a major achievement of twentieth-century structuralism to substantiate the claim that pre-existing relational configurations ("structures") of any kind-conceptual, linguistic, generic-are essential for cultural production. Accordingly, culture as a whole, starting with the first productions by the very first humans, was cast as a process whose logic is ramification, in other words, specification based on previous manifestations of cultural productivity. The metaphor of this approach was, consequently, the image of a tree. Postmodernist theorizing of larger cultural contexts replaced this metaphor with the one of the rhizome (Gilles Deleuze/Félix Guattari). ${ }^{2}$ The main achievement of this approach was the overcoming of the concepts of strictly defined hierarchies and of unidirectional processes which were implied by the tree metaphor.The problem inherent in the rhizome concept might perhaps be characterized as follows: it seems to suggest, even more than its classical predecessor, the image of the tree, a "naturalistic", biology-inspired model of cultural processes, which nevertheless may follow a logic that is independent from the general patterns of the evolution of life. Cultural artifacts differ from biological entities in that they do not necessarily concretize a preestablished program (as encoded in the genes), but are rather subject to relatively free decisions by humans. ${ }^{3}$-The weakest aspect of the rhizome concept may, however, be that it is still all too structuralist, notwithstanding its claims to being poststructuralist: a rhizome is a non-hierarchical, decentered structure; but it is an ongoing replication of one basic pattern that remains identical to itself during the processes of replication.-A last point to be raised critically is the question of the transformation of (visible) forms, that is, of entities consisting of larger quantities of elementary units. In the realm of biological life, such transformations do occur,

2 A Thousand Plateaus, Brian Massumi (tr.), Minneapolis, MN 1987.

3 I do not wish to engage here with the discussion of whether "free will" or "free decisions" are illusions by which we try to hide from ourselves that we are carrying out natural programs; making culture my theme, I stick to surface phenomena and consider nothing but the observable logic of their development. 
but mutations of genes and the (possibly) ensuing emergence of new species are relatively rare; they happen within chronological frames which transcend the existence of human individuals. Culture, in contrast, is characterised by rapid and erratic changes of phenomena. If there is stability at all, it is to be found neither in the pheno- nor in the genotype, but rather in function. Briefly put, if the notion of rhizome is applied to the cultural sphere, its shortcomings are the problem of agency, the overestimation of standardizing with regard to the elementary units of cultural structures, and the undervaluation of morphic change as a distinctive characteristic of cultural evolution.

The metaphor, or rather, metonymy of circulating social energy introduced by Stephen Greenblatt with regard to modeling cultural processes has the advantage of accounting for the high degree of flexibility of the relevant processes. ${ }^{4}$ The risks implied by this concept seem to converge in two points: firstly, there is the question of whether such circulation happens freely, according to a largely non-causal logic (contingency), and by means of an immanent propulsive potential of the material concerned, or whether it is dependent on structures that enable it to a greater degree than is suggested by the assumption of an inherent "social energy". The latter alternative would stress, much more than the New Historicism approach, the discussion of items revolving around the problem of agency: such structures may be established or not; they may be enhanced or restricted; they may be extended or interrupted. ${ }^{5}$ The relevance of these problems becomes visible as soon as one transcends the analysis of "national" circuits. There are incontestable differences to be observed, for example, between early modern English and early modern Spanish drama, which

4 Shakespearean Negotiations: The Circulation of Social Energy in Renaissance England, Berkeley and Los Angeles, CA 1988.

5 In the volume Cultural Mobility: A Manifesto, co-edited by Stephen Greenblatt, Ines G. Zupanov, Reinhard Meyer-Kalkus, Heike Paul, Pál Nyíri and Friederike Pannewick, Cambridge, MA 2010, especially in the Introduction (pp. 1-23) and in the short essay "A Mobility Studies Manifesto" (pp. 250-253), Greenblatt articulates some ideas that are close to my basic assumptions. As is the case here, Greenblatt's argument is directed against the traditional theorizing of cultural phenomena as characterized by "fixity", "coherence”, and "rooted[ness]" (p. 3). He, too, insists on the observation that a highly mobile "global culture" (p. 6) is nothing that is completely new or modern. Greenblatt also stresses the importance of a physical substratum for cultural exchange to take place (p. 250). The main difference between our approaches consists in the way mobility and "rootedness" are conceived of. Greenblatt leaves it at drawing attention to the point that there is a tension between these two parameters, whereas I suggest in what follows a specific relation between them.-The quoted volume contains a number of case studies pertaining to the problem addressed in the title; many of them are interesting, but do not have further theoretical bearing. As to Greenblatt's own case study and to Friederike Pannewick's, which do have such implications, see below, pp. 104-106 and pp. 280-283. 
solicit an answer to the question of what in particular is different in the processes of circulation and where the difference originates. - A second point in Greenblatt's approach which might be worth reconsidering is his assumption of the "separation of artistic practices from other social practices". ${ }^{6}$ This separation is, indeed, crucial with regard to the readers' or viewers' perspective, that is, to processes of reception. ${ }^{7}$ But the extent to which it is appropriate to consider artistic material and other cultural material as separate with regard to processes of transfer and circulation requires further deliberation. Here, too, there is certainly a separation as far as the materialized forms are concerned; paintings and pragmatic manufactured goods may travel on one ship, but as material forms they are distinct and travel as distinct items. Yet the separation seems much more difficult to establish in terms of conceptual forms. It needs to be specified what exactly is transferred when, for example, a dramatic text is "exported" into another country, or even to another part of the same country; firstly, of course, a specific literary text, but along with it, as shall be argued here, all the non-artistic cultural forms and concepts it is made up of (philosophical, theological, anthropological, juridical, political discourses, etc.). Cultural dynamics is to a large extent based on this feature: organized forms (artistic works) are not only transported themselves, but along with them the whole range of non-artistic cultural material they contain.

Is the actor-network theory a possible source of inspiration? The problem with Bruno Latour's numerous publications seems to be that they present prolegomena to a crucial question that remains without a precise answer: what is ANT, ${ }^{8}$ according to Latour? Even in his most recent major work, Latour does not provide a consistent description of what exactly he has in mind. ${ }^{9}$ This said,

6 Shakespearean Negotiations, p. $12 \mathrm{f}$.

7 The most famous narrative text of that age, the Quijote (1605/1615), deals exactly with this problem, in the sense that it presents a hero who seems to be incapable of or not willing to effect this separation.

8 It belongs to Latour's manifold strategies of self-promotion to claim that his theory has acquired a resonance that would call for making use of the above acronym only.

9 Reassembling the Social: An Introduction to Actor-Network-Theory, Oxford 2005. The book abounds in sentences like the following, that is, propositions that stress the difficulties of defining the concept instead of trying to solve them: "It is this increased level of abstraction in social theory which makes ANT hard to grasp at first" (p. 23). A second recurrent pattern are propositions amounting to somewhat banal postmodern standard topoi ("ANT simply claims that once we are accustomed to these many shifting frames of reference a very good grasp of how the social is generated can be provided, since a relativist connection between frames of reference offers a better source of objective judgment than the absolute (that is, arbitrary) settings suggested by common sense.” [p. 30]), or even to statements devoid of any reference, but, as in the example to be quoted, full of metaphorical allusions the inapt profile of which may not even be apparent to the author ("[...] ANT is simply the realization that 
there are some general features of the network metaphor that both my conception and Latour's suggestion of it have in common: the accentuation of the randomness of cultural processes produced by the contingent interaction of very many actors; the relative indifference of the outcome of mediating processes to the intentionality of the mediators involved; the a-teleological and, thus, unpredictable profile of processes of cultural evolution; the importance of "assembly", that is, of putting together diverse materials and shaping them into units the formal consistency of which may be a property ascribed in retrospect; finally, the assumption that when one is dealing with culture, mediation of any kind (even mere "transportation") will affect the material that is mediated.-The most problematic part of Latour's approach may be the fashionable "post-human" features he does not get tired of propagating and which become apparent in such formulations as "objects too have agency".$^{10}$ I shall rather hold on to the view that "objects", in this case material items, do play an important role in processes of cultural, especially literary production, ${ }^{11}$ but that they do not have an agency of their own. The role they may hold is contingent upon the fact that human agency is never a godlike creatio ex nihilo, but always

something unusual had happened in the history and sociology of scientific hard facts, something so unusual that social theory could no more go through it than a camel through the eye of a needle” [p. 106]). In many cases, Latour indulges in displaying a mimicking of what "American academic prose" might be according to the typical immigrant professor. I shall just quote one of the close to innumerable sentences one could adduce in this respect and which are, indeed, quite amusing to read: "I will start by saying that there are four things that do not work with actor-network theory, the word actor, the word network, the word theory and the hyphen!” “'On Recalling ANT”, in: John Law and John Hassard [eds.], Actor Network Theory and After, Oxford 1999, pp. 15-25, quote: p. 15).

10 This is the title of a sub-chapter in the above-quoted book (p. 63). See also p. 71 (“[...] any thing that does modify a state of affairs by making a difference is an actor-or, if it has no figuration yet, an actant" [Latour's italics]). From my perspective, such sensationalist claims are hardly anything other than a relapse into archaic thought-patterns typically qualified as magic. I should mention that Latour frequently revokes the radical claims by which he believes to provoke his readers some pages later; it is one reason for my rather acerbic critique that the author then arrives at statements which are sensible, but at the same time somewhat commonplace, so that the entire discursive move seems to be not much more that rather shallow rhetoric ("ANT states that if we wish to be a bit more realistic about social ties than "reasonable" sociologists, then we have to accept that the continuity of any course of action will rarely consist of human-to-human connections [...] or of object-object connections, but will probably zigzag from one to the other" [p. 75]).

11 To give just one example from the concrete field to be explored in what follows, an example I will come back to at various occasions: had the Ottomans not conquered Constantinople in 1453, had the Byzantine scholars not escaped by ship, or had they only taken with them their personal riches and not their books, the history of early modern European drama would look dramatically different from what it actually looks like. 
based on, and framed by, specific material or object-related parameters the existence of which, in a given place and at a given moment, is in most cases not under the control of the human agents in question.

Following from this brief review, I define as the aims of my theoretical approach to formulate a concept that accounts for the specificity of cultural processes as distinct from natural processes; to conceive a model that enables and favours transnational perspectives; to formulate an approach that allows for an adequate consideration of the problem of agency; to establish a frame that opens up possibilities for the discussion of literary phenomena as at the same time separate from and part of a larger sphere of discourses and cultural practices; to reconsider the dichotomy of teleology vs. contingency as the two main concepts available so far for a conceptualization of cultural processes.

The main implications of this new concept shall be briefly outlined in the following passages of this introduction. ${ }^{12}$ In conclusion, a sketch of the meta-

12 My description turns out to be parallel to some points made by Jan A. G. M. van Dijk's attempt at conceptualizing the present-day world by recourse to this metaphor (The Network Society: Social Aspects of New Media, London 2006; for a similar study with a slightly larger temporal scope, see Armand Mattelart, Networking the World, 1794-1900, Liz Carey-Libbrecht and James A. Cohen [tr.], Minneapolis, MN 2000). As is evident from the subtitles, van Dijk's and Mattelart's approaches differ from my concepts by positing cultural nets and networks as resulting from the introduction of technologies which are linked to modernity in the strict sense (railways, telegraph cables, phone lines, digital media); for an even more pointed approach in this fashion, see N. Katherine Hayles, How We Became Posthuman: Virtual Bodies in Cybernetics. Literature and Information, Chicago, IL 1999. As I shall argue in Part I of the present study, these more recent technological achievements are not negligible with regard to the effects they have on what is produced by the cultural net, but the difference is, more or less, a phenomenon linked to the quantity and the celerity of the material floating in the net. What I shall call the cultural net emerges in principle at the point of human development where the practices of symbolic communication (language, painting) arise. The cultural net as such is nothing particularly modern, but an anthropological constant. Van Dijk does mention in passing human networks previous to modern networks, so the difference between his approach and mine is, more or less, a difference of scope.-For a highly inspiring approach drawing readers' attention to large-scale cultural exchange (without making use of the net metaphor) before the era of modernity proper, see Claude Lévi-Strauss, L'autre face de la lune. Ecrits sur le Japon, Paris 2011.-As to scholarship in the field done so far, I consider Wai-Chee Dimock's description of American literature to display an approach close to mine (Through Other Continents: American Literature Across Deep Time, Princeton, NJ 2006). The focus on the first nation in history that is consciously and intentionally hybrid as far as culture is concerned, marks, obviously, the difference between Dimock's and my investigation, which concentrates on a phase of European history that has so far been conceived of in patterns of relatively hermetic "national cultures". Another publication worth mentioning is Manuel De Landa's A Thousand Years of Nonlinear History, New York, NY 1997. De Landa's highly interesting though 
phor's application to early modern European drama shall be given. This sketch will also contain an overview of problems discussed in more detail in the second and third parts of the book, which present general observations concerning early modern European drama as mass media (Part II) and references to more particular historical scenarios and ensuing theoretical problems (Part III).

2.-A network is a non-hierarchical structure without a center. In the cultural sphere, ${ }^{13}$ it does not originate spontaneously or by means of an extra-human, evolution-driven process. It is, rather, produced by humans and created with deliberate aims. The initial intentions may be fulfilled or not. If they are not fulfilled, the net may be destroyed by those who constructed it. Very frequently, however, network structures which do not evolve according to initial expectations assume other, often unforeseen (and in that sense potentially "revolutionary") functions. ${ }^{14}$-The main purpose of networks is the enabling of processes of transfer of a material that would remain inert without the existence of such structures.-Net structures may be set up anywhere and everywhere. Apart from the will to set them up, they do not need any further specified substratum.-There is no entelechial form of a net. Nets are never complete. They are not created once and for all. Nets may thus extend and ramify to regions which are completely unknown to those who set them up.

As soon as they exist, even net structures functioning according to initial purposes frequently come to transport not only the specific material for whose circulation they were created, but other, at times completely heterogeneous material as well. This happens in many cases without being noticed, at least for some time. Cultural transfer in particular has been taking place for long periods in the species' history as a "by-product" of circulation processes within network structures whose purpose was not primarily cultural, let alone artistic. It is in many cases a parasitic phenomenon linked to processes organized in view of economic or power-related aims; for that reason, the strictures to which

somewhat general observations try to apply basic insights of thermodynamics to the question of what keeps human "history" moving.

13 The term is meant in its etymological sense (from Latin colere), that is, as referring to any activities-not only artistic ones-by which humans produce items that do not exist in the natural world.

14 One might think in particular of the network established between Europe and the Americas, starting in 1492. Its original purpose was merely economic; its establishment was motivated by the quest for an El Dorado in the literal sense of the term. Especially with regard to South America, it became an infrastructure for the perhaps most important and most radical transculturation in the species' history, as early as from the first decades of the sixteenth century onward. 
the circulation of cultural material is submitted may be less rigid than is the case for the spheres of material goods and physical power. Even in later times, when there are conscious transfer processes of cultural material, it seems to be a specific feature of the form of floating-in-the-net unique to cultural material to be less restricted in terms of homogeneity than circulating physical items. ${ }^{15}$ Cultural "innovation" very frequently ${ }^{16}$ is a consequence of a transfer of heterogeneous material that in many cases remains unnoticed, and may even have been rejected had it been noticed.

The commonalities with more "common" networks notwithstanding, cultural nets are a specific variant of network structures. ${ }^{17}$ The main difference with regard to regular networks consists in the fact that cultural networks may

15 One might think about attributing this reduced requirement as to homogeneity to the "complexity" of all cultural items, in contrast to the rather simple, standardized structure of all material items. To give an example: if a specific country decides to define rules for agricultural or industrial products allowed to be transferred to the territory it controls, the examination of such items according to these rules is a relatively easy task. With regard to cultural products also, many countries have defined rules for allowing concrete items to be transferred into their territories; but due to the multifaceted semantics of all cultural items, it is difficult to determine what is still within the limits-and what should be rejected as subversive. Strictly totalitarian countries try to cope with this problem by taking measures intended to completely cut off their countries from the universal cultural net. But, as history demonstrates, this is almost impossible (as to possible reasons, see below, Part I). Subversive material finds its way, sooner or later, into totalitarian countries also-which may be an important reason why rigid totalitarian systems have never been sustainable structures.

16 The above qualification is meant to refer to the huge divide that separates the mechanisms of cultural production from the era of Romanticism onward from all previous eras of Western and non-Western culture. When "innovation" and "originality" become the main parameters of valuation, the archaic concept-active in many societies up to the present-of controlling and thus restricting the movement of cultural material becomes replaced by an attitude that is shaped by the permanent attempt at enhancing such processes.-As I shall stress in a later footnote (n. 34), generalizations such as the one just formulated are always in need of a benevolent reading; the replacement of the parameter of "control" by the one of "enhancing innovation", taking place at the inception of cultural modernity proper, that is, around $1800 \mathrm{CE}$, is, of course, a tendency which seems to become more and more dominant; meaning: as recessive phenomena, there are instances of controlling cultural circulation processes by way of authoritarian means also in the era starting with Romanticism (see n. 283).

17 In order to avoid misunderstanding, I should like to express that the metaphor of the net as intended here has little or close to nothing in common with the primary meaning as apparent in terms like "fishing net". As is almost always the case when the same term is employed in order to designate different objects, there is, of course, some commonality between net structures as characterized above and a fishing net. The highway system of a densely populated country like Germany, viewed from a bird's perspective, and a fishing net, viewed through a magnifying glass, will look pretty much alike. But in terms of function, the two variants of net are radically different. In a road network (as in the cultural net here theorized), all motion 
have a stable material substratum or not; in any case, they need a material substratum, but not necessarily a stable one. ${ }^{18}$ In that sense, their character is in most cases virtual. ${ }^{19}$ This virtual character may be specified in two different, but complementary ways: as mentioned, up to the age of sedentary life, cultural transfer is in almost all cases a parasitic phenomenon taking place within network structures whose purpose is not the circulation of cultural items. ${ }^{20}$ The second dimension of the basic virtuality of cultural networks, which also applies to later periods including the present, concerns the variance of the physical substratum: in contrast to road networks or pipeline systems, cultural transfer is almost always ${ }^{21}$ a process taking place by means of a variety of specific media.-This high degree of virtuality of cultural network structures is facilitated by the circulating items. "Culture" conceived in the broadest possible way, that is, as consisting of all activities by which humans transform their nature-given habitats, differs from elementary processes of customising

takes place inside the various strings that constitute the net. With respect to a fishing net, all motion (of water, of fish) takes place in between the strings. The purpose of a road network is to enable motion, the purpose of a fishing net is to restrain motion and to finally reduce it to point zero (the "catch"). A road network and all similar net structures (electric grids, railroad systems, flight routes, postal transport systems, etc.) are media, that is, indifferent at least to a certain degree to the purposes for which they are used; in the case specified, they may serve in order to circulate private cars, trucks, or tanks; the intention linked to the processes of motion may be touristic, economic, or military. Fishing nets are not media, they are instruments. They serve one purpose and one clear-cut intention. (For evident reasons, I pass over re-functionalizations such as the exhibition of fishing nets in museums.)

18 I should like to draw readers' attention to the fact that it is mainly this point which differentiates the phenomenon here theorized as "cultural net" from the phenomena apostrophized by the common use of the term. See pp. 34-45 for a more elaborate discussion of the point.

19 The modal qualification ("in most cases") refers to the trivial fact that there are obviously non-virtual structures involved whose observation is, however, bound to narrowing down the local and temporal scope. The distribution of printed books, e.g., in the era of multinational publishing companies may be described as taking place within "real", materially manifest network structures. But when it comes to the question of how the concepts contained in these books circulate within the community of readers and also beyond, the assumption of these processes taking place within network-like structures seems as plausible as the pretense seems problematic that these structures compare, as to their "material" essence, with networks such as standardized mailing services (etc.).

20 In the chapter "Borderlines", I will present some speculations concerning the question of what these early processes of cultural transfer might have looked like.

21 In very recent times of human history, there are, of course, network structures transporting cultural material which do have a stable physical substratum, the most prominent ones being TV networks or the Internet (radio waves). Their predecessors in terms of media history were publication companies, or state agencies created with a view to circulating cultural material to other countries. 
natural habitats to be observed among animals in the sense that it exists in two different registers bound to each other: as material forms, and as conscious concepts which inform the respective forms or can be extrapolated from them. This "double nature" of human culture is of a high relevance with regard to processes of transfer. Cultural networks primarily contribute to transferring the conceptual forms underlying the actual artifacts. The material forms may "travel" as well (paintings, statues, books), but this does not constitute a necessary condition for cultural activity and exchange. ${ }^{22}-$ Yet the circulation of conceptual forms also needs a material substratum in order to take place. In the periods of human history preceding the establishment of institutionalized infrastructures for circulation (the print industry; TV; the Internet), this physical substratum consists most frequently of circulating humans (merchants, warriors, courtiers or diplomats, future spouses, religious officials, academics, artists).-In many cases, such transfer processes take on the shape of "chains" of the human agents involved. A story migrating from China to Europe or vice versa will have been transported by quite a few human mediators, who may have pursued very diverse intentions when transporting the cultural material in question.

The movement of material mediated by cultural net structures is not exclusively unidirectional. It remains to be discussed in detail whether this aspect can be better accounted for by conceiving of cultural networks as being organized according to circuit structures, or whether it is more adequate to assume them to be shaped according to a pattern of roads. The advantage of the latter alternative consists in that, in such structures, inverse movement of the transferred material is possible, but not compulsory, mandatory, or necessary. Total reciprocity and the complete absence of hierarchies as a feature of culture may be as problematic an assumption as the obsolete metaphor of culture as a tree. ${ }^{23}$

22 In that sense, the circulation of "ideas" in the Platonic sense (the "idea" of a table, or a house) would be conceived, from my perspective, as taking place within what I here try to theorize as the cultural network; there are, however, certain characteristics of cultural items in the sense of concepts informing artworks which distinguish them with regard to their way of "floating" (and also with regard to the virtuality of the floating process) from the floating of other non-material, but pragmatic items such as "ideas" or blueprints (in present-day times). I shall address this point in the subsequent paragraphs.

23 In that sense I should like to distance myself from more politicized approaches to the question of cultural exchange as advocated, say, by Gayatri Chakravorty Spivak (see, amongst other titles by the author, Death of a Discipline, New York, NY 2003). As legitimate as Spivak's plea for a de-Westernization of what we presently understand by "World Literature" (or "global culture") may be, there is no way to change the past; as William Occam, following Aristotle, argued, even an omnipotent God is not able to accomplish that. The past may be unjust, it may be the result of aggression and subjugation, but it is factual. And there is no evidence that communities "subalternized" by the Western powers in the age of imperialism were morally superior; they were either technologically less developed, or less fortunate, or both. 
Since they are constructed and operated by humans, networks, including cultural networks, are subject to the human will as far as their capacity for transportation is concerned. They may be extended, or, rather, parts of them may be extended. They may be restricted or interrupted temporarily, or even be destroyed completely. The transported material may be allowed to circulate freely, or it may be submitted to a more or less systematic scrutiny and then allowed to travel on or not, or partly so. In the period of interest here, these regulatory activities are performed by institutional agents. ${ }^{24}$ These agents are not contingent upon the material circulating in the net, but obey an external logic. If agents of control are not changed from time to time, they may be affected by the material under review and thus fail to exercise their task.-The rationale of control may be motivated by ideology, authority (power), or economic considerations. It may be an illusion that movements within the cultural net are exclusively or even mainly driven by immanent quality standards.-The reasons for regulation do not exist in "pure" versions, but as specific and varying configurations of the three above-mentioned components. In almost all observable cases, there are internal frictions between the components. Much of cultural difference, in the age under consideration but in other ages and places as well, seems to result from divergent regulatory factors. In the early modern world, just as in the present, different concepts of what constitutes the "right" form that regulatory rationales should take provoked "culture clashes".

Cultural production is, from this perspective, a process that is primarily based on the withdrawal of elements already circulating in the net, in contrast to material production, which is mainly contingent upon raw material deriving from external sources. ${ }^{25}$ In both cases, the material is submitted to a pre-con-

24 The Inquisition set up by the Roman Catholic Church in the thirteenth century and reshaped into a bureaucracy in the sixteenth century is the prototype of all posterior institutions of censorship. It needs to be stressed that it would be nothing but an idealization of more pristine periods of human culture to assume that such processes of controlling the material floating in the cultural net had been inexistent before. It is well known that the Egyptian pharaos as well as the Roman emperors did not only promote certain cultural productions, but also worked with the intention to repress or even eradicate items which did not comply with their ideas; what was still absent is the institutional frame, the pattern of an agency of control as a permanently existing bureaucratic structure. Besides the activities of those in power, there are in all human societies, with the relative exception of some present-day Western-European societies that value personal freedom above all else, informal mechanisms controlling cultural activities. These mechanisms are usually called norms or values; they define what may be articulated and what must not be articulated.

25 My formulation implies that "material" production is part of cultural production lato sensu, since the "shaping" of the raw material is done according to concepts which are in most cases not original, but are-if not pre-typified anyway-recombinations of previous concepts. This said, I believe it to be reasonable to consider the manufacturing of goods as not completely 
ceived conceptual shaping; but it seems to be an important characteristic of the "material" extracted from the net with a view to cultural production in the artistic sense that it is, in many cases, conceptual only, or, if physical (paintings, statues, texts), informed by concepts that may be extrapolated from the materialized forms.-Circulating material may be withdrawn from the cultural net at any given point. At least up to the age of copyright laws, the withdrawal is free of charge. ${ }^{26}$ As soon as withdrawn, the material is shaped into formally defined entities by humans, individuals or groups. This shaping consists in most cases in a "novel" combination of single items moving in the net.-It is of primary importance for the specificity of the movement of artworks (that is, of goods that are not immediately pragmatic) ${ }^{27}$ that they may be conceptualized as circulating at the same time as ready-made works (texts, painting) and as components into which these might be decomposed. ${ }^{28}$ In order to characterize the corresponding processes, I will suggest the metaphors of "assembly" and "disassembly", specifically with the intention to stress the "technical" aspect of artistic production, rather than the "creative" one (in the literal meaning of the term).-In case the material is language-based, the first step of formal shaping is the homogenization of differing symbolic codes (languages) if necessary, that is, whenever the floating elements cross linguistic borders.The levels of formal organization typically attained differ dramatically. ${ }^{29}$ Established hierarchies of cultural products ("low" and "high" culture, popular and

identical with the "creation" of art works. The differences as well as the commonalities are captured in a quite adequate fashion by a terminology (artes liberales; artes mechanicae) which has disappeared in modern times under the pressure of Romantic art theory.

26 I should like to argue that this applies to later periods as well. What is fended off by copyright regulations is flagrant (verbatim) plagiarism. But, to take a famous case, no one could have hindered Fontane from rewriting Flaubert's Madame Bovary (1857) as Effi Briest (1896). In the course of the reception, it is the aesthetic and conceptual productivity originating from such configurations which decides whether the later text is received as a great work of art or as a poor, epigonic imitation.

27 For the reasons touched upon in passing above, I will not use the current term of depragmatized goods for artworks in general. As useful as the dichotomy of pragmatic and depragmatized may be for all of specifically modernist art, it is problematic with regard to previous art production. Of course, there is a difference between a catechism and a religious drama, or between a collection of laws and a dramatic text that deals with the fate of personages transgressing these laws. But what may, indeed, be a dichotomy in modern times may have been a gradual difference in previous periods of human history. Such a statement does not imply that the difference is negligeable in theoretical terms.

28 At a later stage of my argument, I will come back to a third way in which artworks may move in the net: as abstractions (of various levels) by way of which they might be condensed. 29 We commonly differentiate between highly organized and less highly organized texts as "canonical" literature on the one hand, "popular" literature on the other. 
elitist) are mainly contingent upon the level of formal shaping and its recognizability in a given work.-The formal entities (works) are then "used" with regard to different functions, mainly didactics, entertainment, and reflection.

Since they exist in a material as well as in a conceptual mode, the entities originating from the cultural net are inconsumable, at least as long as the human mind exists. After having been used, they continue to exist, in some cases both in the material and the conceptual mode (paintings, books), but in any case in the conceptual mode. They are stored in what could be summarized under the formula of "the human mind (in general)", that is, in the collective memory of the species, while this concept is not meant to refer to a common memory-which hardly exists before the epoch of thoroughgoing globalization-but, rather, to a random inventory of items of various grades of organization present in the memory of the diverse cultural communities constituting the species in its entirety.-After the accomplishment of one such novel artistic item, the previously existing material as well as its new shaping are re-absorbed by the material circulating in the net and continue their potentially endless travel.-As is true with regard to physical networks, e.g. road networks, the circulating material may assume different degrees of formal organization, from the level of elementary components up to the level of organized entities capable in certain cases of being auto-motive within the net-- Since cultural items in most cases ${ }^{30}$ have been floating in the net rather in the conceptual mode before the inception of the technological era and its invention of standardized duplication (print) along with the establishment of generally accessible material archives (libraries, traditional or electronic), the new synthesizations may, in principle, be considered to continue floating in either a synthesized or a decomposed fashion. - The fact that the material circulating in cultural nets is not homogeneous (in the sense of not being formally standardized) is a strong plea for discarding alternative metaphors, such as a web or grid, which might in principle be considered as well.

Literary texts could, from this perspective, be characterized as a configuration of cultural material organized with a view to all three above-mentioned functional dimensions (didactics, entertainment, and reflection). The relative weight of each purpose varies from work to work and is subject to reassessment

30 Even in the pre-technological era, certain manuscripts or artworks, such as statues, were circulated as gifts or for cultic purposes; but these pre-technological processes of circulation of finite works cannot be compared, in terms of quantity or qualitative impact, to what happened as soon as industrial copy techniques were introduced. 
from the perspective of different recipients. Pragmatic cultural texts, ${ }^{31}$ in contrast, are mainly characterized by just one of these functions; there may, however, be traces of the non-dominant functions in pragmatic texts as well, as in the case of the pleasurable, in a way "entertaining" presentation of a philosophical text or of a religious sermon. ${ }^{32}$-Drama may be considered a particularly interesting phenomenon in the context of a network theory of cultural production and reception, insofar as it comprises textual and, as soon as performed, non-textual configurations of pre-existing cultural entities. It may thus allow for a more refined description of the "interaction" between strictly textual and non-textual forms of cultural practices.

3.-The following part of this introduction is dedicated to briefly characterizing the specific period and the specific texts by which I shall try to illustrate and differentiate my theoretical speculations in the more extended presentation of the theoretical approach (Part I) and in the subsequent Parts II and III, where I will focus on concrete phenomena and configurations. These texts are taken from the corpus of early modern European drama.

The early modern age bears its name because the basis of modernity proper was cast in that period. This applies to the natural sciences, ${ }^{33}$ religion, ${ }^{34}$ politi-

31 I pass over the question concerning the status of scientific texts as well as of those texts, such as political treatises, which first emerged as separate corpora in this period. The theoretical problems involved are addressed in a satisfactory fashion within Niklas Luhmann's thesis of modernity as an age of ever-growing functional specialization, that is, separation of discursive items which in former periods constituted one section of the discursive field (the latter term according to Michel Foucault, L'Archéologie du savoir, Paris 1969, pp. 44-101; as to Luhmann's theory of modernity, see Social Systems, John Bednarz and Dirk Baecker [tr.], Stanford, CA 1995).-Need I stress that I will not try including cultural items like music or painting in my tentative theorizing? This said, I believe that the theoretical speculations offered above may be useful, mutatis mutandis, for the non-verbal arts as well. Accordingly, there will be some occasional hints at these art forms.

32 This latter point and the aforementioned aspect that different purposes inform a literary text to different degrees may account for the affinities between certain literary and certain non-literary texts, mainly philosophical or religious. "Literature" as strictly distinct from the other discourses is not a phenomenon, it is an ideal concept, and one should even consider the hypothesis that it came into being only with the rise of philosophical aesthetics, that is, at the end of the eighteenth century (Kant, Critique of Judgment [1790]).

33 I am referring to the theoretical foundation of empiricism and of rationalism.

34 The main point is the establishment of (intra-Christian) religious pluralism as the result of the Thirty Years War.-As with every generalization, my remarks, particularly in this introduction, are in need of a benevolent reading. Since it is evident that I will be dealing with "Western" literature in this book, although my general theoretical approach tries to go beyond such firmly established borderlines, or, rather, tries to re-conceptualize them in a much less dichot- 
cal organisation, ${ }^{35}$ political theory, ${ }^{36}$ the understanding of Scripture, ${ }^{37}$ and the general model of world and cosmos, to name the most important points only. In all these respects, European societies crossed a threshold of global historical importance: the abandonment of cyclical conceptualizations of time and the introduction of the concept of possibly never-ending "progress". ${ }^{38}$ It was this conceptual distancing from the cyclical model which laid the foundations for the effective material transformation of the world beginning in the eighteenth century, that is, industrialization.

According to the dominant view as emblematized in the term "Renaissance", changes in the cultural sphere in general and in the literary sphere in particular were much less radical. The overcoming of medieval patterns is supposed to have largely taken the path of reactivating an existing paradigm, the culture of classical antiquity, blending it with a limited set of "new" ideas. Early modern culture would thus have to be subsumed under an age that begins already in the middle of the fourteenth century. ${ }^{39}$ Cultural modernity proper-understood as the emancipation from culture as cyclical recurrence-would thus set in only during the Enlightenment, or rather with the age of Romanticism and its anti-classical, anti-normative turn. Early modern literary culture would be, as it were, belated with regard to contemporary scientific progress, philosophical achievements, or even religious diversity.

The drama of the period, however, is an apt example for showing that these current views neglect important, even crucial traits of the cultural dynamics of that age. Sixteenth- and seventeenth-century European drama was, indeed, inspired by classical models (mainly Seneca and Terence) and by classical poe-

omous way than usual, I do not consider in the above remark the problem of the schism between Byzantine and Roman Christianity, which occurred as early as at the end of the first millenium CE. This hint is meant to apply to all other generalizing statements in this introduction as well. I leave it to my readers whether or not they find my generalizations useful. As to the point in question, I believe it to be legitimate because there is a difference between religious pluralism existing in territories otherwise, that is, politically unified, and a plurality that does not require a theoretical effort because it exists with regard to territories otherwise separate from each other.

35 I am thinking of the "invention" of the centralized and bureaucratized modern state.

36 Absolutism as well as international law were first theorized in that age.

37 A pervasively allegorical reading of Scripture, in contrast to the selectively allegorical interpretation practiced since Origen and Augustine, and the ensuing destabilization of the concept of the "one and ever identical truth" arose only in this age, within certain Protestant denominations (the quote is from Augustine, De vera religione III: 3 ["veritas una et eadem semper"]). 38 See my essay "The Traditional Cosmos and the New World”, $M L N$ vol. 118/2003, pp. 363-392. 39 I am referring to the (finally not misled) cliché of Petrarch as the "father of humanism". 
tology (neo-Aristotelianism). Nevertheless, it differs fundamentally from its sources. The pragmatic context in which dramatic performances took place changed substantially. In that period, drama as performance established the basis of a new cultural practice that has become the main element of presentday culture, occidental and non-occidental: visual culture as mass media. In the terminology of the above-characterized theoretical approach, the particularly fascinating characteristic of this subgenre of literary texts consists in redefining what literature is meant to be by fusing more traditional functions of drama and theater with pre-existing functional dimensions circulating in the cultural net that had up to that period belonged to the domain of other types of cultural practices, mainly religious. ${ }^{40}$ This rather significant "leap" in terms of cultural practices may be observed in all major Western and Central European countries, with slight differences regarding periodization: first in England, then in Spain, and some decades later in France and Germany. The prehistory of the development is to be found in early sixteenth-century Italy, where one might rightly speak of a "Renaissance", as we are dealing mainly with a revival of classical models. The new cultural patterns spread rapidly, by way of a virtual network as outlined above, to other Western and Central European countries (the Netherlands and Scandinavia, Portugal, Poland, and the non-German-speaking parts of the Habsburg Empire), where they came in contact with a partly still existing local theater culture which goes back to the shared European tradition of medieval Christian drama (morality plays, mystery plays). ${ }^{41}$ Roughly one century later, they were transported by the infrastructure of the cultural net to a part of Europe which up to that period did not have a refined dramatic production of its own, ${ }^{42}$ Russia. And another century later, they spread to colonial India, where they initiated a visual mass culture that might see its greatest impact only in the twenty-first century.

The primary common characteristic of early modern drama is to have been written for stage performance, thus differing from (early) Renaissance drama,

40 In the further course of my argument, I shall come back to the intricate question as to what, in essence, differentiates the performative practices of theater from Mass (pp. 167-171). 41 The nomenclature for the subgenres of medieval didactic drama differs from one vernacular to another, but in all the relevant "national" theater cultures there is the bi-partition designated by the above English terms, namely, dramas which are meant to be primarily moralizing, and which make use of the device of allegory-mostly in the sense of personifications of vices and virtues-and, secondly, dramas which present the miracles and mysteries from biblical history and the saints' and martyrs' lives.

42 The adjective is to refer to the fact that there were, in pre-eighteenth-century Russia, elementary performances one might compare to medieval farces, as well as liturgical plays; but there was no drama proper. 
which was conceived mainly to be read, particularly when it was not intended for the court. ${ }^{43}$ This entails a radical change of recipients. Early modern drama addressed highly diverse audiences, from the illiterate to the intellectuals and the nobility. As such, its themes and objectives underwent a fundamental transformation: the refined and elitist Renaissance culture became replaced by a mass culture, a phenomenon which would affect the other genres, mainly narrative, only in an age when literacy became ubiquitous, i.e. in the nineteenth century.

Early modern drama was performed either in institutional theaters ${ }^{44}$ and theatrical courtyards (corrales), depending on climate conditions, or on carts, by itinerant companies. Performances were public in the sense that everyone who was ready to pay an (affordable) fee was admitted. It is mainly the features of common accessibility and of presentation-as-performance which may be considered as being drawn from another cultural configuration floating in the net, namely the practice of religious service, of Mass. ${ }^{45}$ It is evident that the intensity of circulatory processes increases dramatically as soon as the (illiterate) masses become connected to the cultural network. A comparison with religious drama in the strict sense, which went on existing in certain countries-mainly Spain-allows for the determination of the difference between early modern drama and the medieval drama performances which were commonly accessible as well, but re-

43 I am thinking in particular of a text such as the most famous drama of that period, the Celestina (1499/1504). As to the intellectual depth of the play, which is from my viewpoint one of the most significant texts of European early modernity, see my "Mittelalterlich kosmische Ordnung und rinascimentales Bewußtsein von Kontingenz. Fernando de Rojas' Celestina als Inszenierung sinnfremder Faktizität (mit Bemerkungen zu Boccaccio, Petrarca, Machiavelli und Montaigne)”, in: Gerhart v. Graevenitz and Odo Marquard (eds.), Kontingenz, München 1998, pp. 173-223.

44 Court theater, which emerged at the end of the fifteenth and the beginning of the sixteenth centuries, goes on existing, but becomes more and more a receding phenomenon; this said, it remains an important site of cultural floating processes and will thus be addressed in due terms in the following sections of this book.

45 In English, the relation established by me between early modern drama as the first instance of visual mass culture and the religious practice of the (Catholic) Mass may seem confusing, or to be yet another of the somewhat outdated examples of postmodernist playing with signifiers. In my own language, there is no such equivalence regarding the signifiers implied. Mass media reads "Massen-Medien" in German, while the word for Mass is "Messe". Accordingly, my above remarks are meant seriously; they refer to the signifieds of the respective terms: early modern drama applies the feature of general accessibility to a performance, which is derived from religious ritual, to a cultural practice that was characterized by restriction up to that period (literacy, and the quite extensive financial as well as cultural resources that it requires). For further differentiations, see below, pp. 167-169. 
stricted in time because they were bound to the most important festivals of the Christian calendar, primarily Christmas and Easter: the theater as created in the sixteenth century CE establishes for the first time in human history the practice of a public visual culture that is not bound to ritual patterns (religious, or, as was the case in classical Athens, political) and the ensuing constraints. ${ }^{46}$

The research conducted so far on early modern European drama ${ }^{47}$ has been confined to the companion-style monograph; the relevant books largely lack a discussion of extra-literary discourses and follow traditional patterns of literary history, including some general remarks regarding staging. Numerous articles in journals or in collective volumes which pursue a comparative perspective are mostly restricted to a more or less updated variant of motif history or to comparisons between single works of specific authors. ${ }^{48}$ Highly sophisticated new approaches to great dramatic authors of that age, such as Stephen Green-

46 These constraints are highly diverse, but regardless of the difference, they have in common the restriction of the process of circulation of cultural material. As to religious ritual, there are content-bound (dogmatic) strictures; in addition, there are processes of automatization and the ensuing reduction of receptivity. As to the first documented theater culture in human history, it is a frequently neglected point that the term "democracy" meant something different in fifthcentury-BCE Athens than it does in later times. Not only those entitled to vote, but also those admitted to theatrical performances were a relatively small minority of the population (adult "free" citizens, males and their wives); children, adolescents, slaves, and metics were not admitted.

47 Meaning: there are, of course, a lot of important, separate publications on English, French, German, and Spanish drama of the period (see my remarks below).

48 The most recent instance of these theoretically more traditional undertakings is the Theater Without Borders project conducted by Robert Henke et alii, which has resulted in two collective volumes so far (Robert Henke and Eric Nicholson [eds.], Transnational Exchange in Early Modern Theater, Burlington, VT 2008, containing an "Introduction" by Henke describing the entire project [pp. 1-18]; Robert Henke and Eric Nicholson [eds.], Transnational Mobilities in Early Modern Theater, Burlington, VT 2014). Although the research project comprises certain theoretical ambitions, its main focus is on the description of singular phenomena of cultural exchange within the frame of early modern European theater. The approach is comparative, but English theater is the pivotal point of the research carried out, with a secondary focus on Italian theater.-I should like to stress something that is, to a certain extent, evident from the titles published by the team: much more than is the case here, the accent is on theater in the sense of performance, while texts are of minor importance. This attitude limits to a considerable extent the theoretical bearing of the discussions. The entire question of cultural transfer, for instance, is linked to a large extent to the point of specialized human intermediaries, that is, wandering troupes, and not to the multifarious and even unintentional processes of transmission that result from many different forms of "migration" of humans and of material objects. As to the detailed description of various specific practices of cultural exchange in that period (itinerant theater troupes, "migration" of motifs and character types, or of performative practices from one country 
blatt's publications on Elizabethan theatre ${ }^{49}$ have considered the questions raised by early modern theater from the perspective of one particular "national" culture; exogenous sources, mainly Italian and French, are taken into consideration if applicable, but the perspective as a whole is not comparative. This applies as well, mutatis mutandis, to Antonio Maravall's research on the Spanish Golden Age drama. ${ }^{50}$ Maravall characterizes the corral theaters as part of a propaganda system, which is a hypothesis worth being considered; ${ }^{51}$ but the focus on Iberian drama entails certain limitations with regard to a possible generalization of this thesis. Walter Benjamin's essay on German Baroque drama is still a source of inspiration, ${ }^{52}$ as is Albrecht Schöne's monograph on emblem books and German Baroque drama, ${ }^{53}$ which was the first publication to draw attention to the close links between drama and the visual culture of the age.-Succinctly expressed: the research done in the field is committed, in a way that remains unproblematized for the most part, to a framing which is contested by the theoretical approach here submitted, namely to the concept of "national literature", in the sense of an "organic" relationship between the conceptual and the linguistic level of a given corpus of literary texts, which entails conceiving the latter as being linked to a specific configuration of pragmatic parameters.

What might be the results of a new approach to early modern European drama according to the concepts outlined in the first part of this introduction? The

to another, etc.), the volumes mentioned are a highly useful source. Over the years, the team has become more and more committed to Louise George Clubb's concept of "theatergram”, which I do not discuss critically here; suffice it to say that it is evident from my entire approach that the restriction of the investigation to borders established by genre seems to me as problematic as restrictions established by language or by "national" borders. Dramatic texts, to put it briefly, are very frequently based on non-dramatic (narrative) texts, and also share very many features with them; following Aristotle, I consider opsis to be a relevant, but not the most relevant component of texts conceived with a view to being performed on stage (Clubb, Italian Drama in Shakespeare's Time, New Haven, CN 1989).--The Theater Without Borders and the DramaNet research teams exchanged their views on the occasion of several conferences (see, e.g., Joachim Küpper and Leonie Pawlita [eds.], Theatre Cultures within Globalising Empires: Looking at Early Modern England and Spain, Berlin and Boston, MA 2018).

49 See, once again, Shakespearean Negotiations.

50 Culture of the Baroque: Analysis of a Historical Structure, Terry Cochran (tr.), Manchester 1986.

51 See also Greenblatt's similar views with regard to the situation in England ("The Elizabethan stage functions as one of the public uses of spectacle to impose normative ethical patterns on the urban masses." [Renaissance Self-Fashioning, Chicago, IL and London 2005 ( $1^{\text {st }}$ print 1980), p. 253]).

52 The Origin of the German Tragic Drama, John Osborne (tr.), London 1998.

53 Emblematik und Drama im Zeitalter des Barock, München 1964. 
most important point might consist in the fact that a network theory of cultural production frees the texts and the actual practices from being considered within the boundaries of national cultures. Transculturality would thus become the standard case, while "nationality" of cultural artifacts would be considered the particular case to be explained according to the logic of control outlined above (mainly: power- or belief-driven attempts to restrict the material available at a given time and place). Common traits between spatially or temporally separated works of art would no longer have to be considered an astonishing phenomenon. Reception in later times or in remote regions could be accounted for either by the varying impact of the aforementioned three basic control mechanisms, by the expansion of the net structure, or both. Fundamental formal standards that can be observed in all European "national" cultures could be explained by considering the floating of the material on differing levels of formal organization, including abstract instructions of formulation: shaping thus need not start at the basic level whenever a quantity of material is extracted from the net in view of being shaped. Relative difference with regard to form could be accounted for on the grounds of the possibility to impose any form on the material circulating in the net.

4. - In order to give a first impression of the outlined theoretical hypotheses' viability in relation to the field in question, early modern European drama, some points shall be illustrated by referring briefly to authors, texts, and cultural materials which are still well known today.

The most prominent English drama of the period is Shakespeare's Hamlet (ca. 1600); for Spain one would have to point to Calderón's La vida es sueño (ca. 1635). Both dramas rely on source material from other authors, but there seems to be no direct influence that the Shakespearean play could have exerted on Calderón's comedia. Nevertheless, the commonalities between the two texts are striking. ${ }^{54}$ Their basic plots build on the oedipal triangle: ${ }^{55}$ a young prince

54 For a more detailed comparative analysis of these two dramas, see my "Hamlet, by Shakespeare, and La vida es sueño, by Calderón, or the Problem of Scepticism”, Germanisch-Romanische Monatsschrift vol. 58/2008, pp. 367-399.

55 I take the occasion to draw readers' attention to a point that needs to be addressed in my further analyses: are there anthropological constants grounded in our belonging to one species that could account for certain observable commonalities between texts of different or even separate cultural contexts? Or, to put it more precisely: on which level of formal and contentrelated organization should these anthropological commonalities be assumed to be located? As is well known, Sigmund Freud claimed that the oedipal triangle is in a way related to the existence of culture as such. Mid-twentieth-century structuralist anthropologists such as Claude Lévi-Strauss would have agreed, though from a different theoretical vantage point. The experience to be made in the present-day, rapidly globalizing world, however, raises questions concerning the commonality of patterns such as the one mentioned. It seems not to exist in 
struggles for power and is opposed in his efforts by his father, or by a fathersubstitute, respectively. The mother figure (in Calderón's case a mother-imago) holds an ambivalent position between the two conflicting male characters. The main difference consists in that, in Shakespeare, the oedipal material has been assembled into a tragic pattern, whereas in Calderón the conflict is resolved by a fairytale-like ending, as is standard in comedy.-The two dramas do not only make use of the same material regarding the basic plot, but also with regard to the fundamental concept underlying the plot. In both plays, what is at stake is the problem of the reliability of sense perception. In Calderón, the question emblematized by the play's title is a sort of "direct" extraction of material floating in the net, namely, the fourth trope of Sextus Empiricus' summary of the basic theorems advocated by Pyrrhonian skepticism. In Shakespeare, the question as such, which is none other than the one raised in Calderón, becomes linked ("assembled") to a material whose provenance and profile is more popular than in Calderón, namely, the existence or non-existence of apparitions authenticated by sensory perception, of "ghosts". In both plays, the "epistemological" problem is linked to material deriving from moral-philosophical discourses, namely to the question of the conditions of certainty regarding knowledge about what has happened under which it is ethically justifiable to take another person's life.-While the oedipal triangle provides for entertainment by gratifying the spectators' more or less conscious libidinous desires, in the sense of both sex and aggression, ${ }^{56}$ the endings refer to specific world-models related to the generic patterns mentioned. ${ }^{57}$ The basic question

\footnotetext{
traditional Islamic societies or in Far Eastern contexts. It cannot be excluded that the "commonality" of the pattern in the West originates in its circulation in the occidental section of the cultural net, which may have started before Sophocles wrote his drama; Gen 3 might be a historically much older instance. This said, the decisive question would remain to be resolved: why is it that particularly this interactional pattern was "extracted" from the net so frequently in the course of Western cultural history?

56 I am referring to Freud's-in my opinion highly convincing-attempt at theorizing literature in the sense of fiction ("The Relation of the Poet to Day-Dreaming" in: Art and Interpretation: An Anthology of Readings in Aesthetics and the Philosophy of Art, Eric Dayton [ed.], Orchard Park, NY 1998, pp. 300-304). The sophisticated formal organization of "high canon" literary texts is, according to Freud, nothing but a structure of enticement allowing the cultured recipient to approach these works with the conscious intention of satisfying the intellect, while then (and thereby) indulging, mostly subconsciously, in libidinous configurations and fantasies the direct "consumption" of which would otherwise be contravened by a strict veto from his or her superego.

57 It is, indeed, a simplification to apostrophize Catholicism as an interpretation of the Christian dogma according to the basic pattern of comedy, but I suggest considering it as a useful one, and my view may invoke an authority as important as Dante. I shall not engage in the discussion of whether Shakespearean drama is written from a standpoint informed by Catholicism (which I would exclude from my perspective), Protestantism, agnosticism, or even athe-
} 
underlying the plot connects the plays to contemporary philosophical and epistemological discussions (skepticism), and the aspect under which this question is integrated into the action establishes, as already said, links to moral philosophy. In both dramas, there is a host of additional cultural material to be found, deriving from religious or theological discourses (the question of hell and purgatory; opera meritoria as useful or not, etc.).-All these materials could be considered as items floating in the contemporary cultural net. They precede the works mentioned and are not individual "creations" on the part of the playwrights. This implies that, at other points within the net, there is a high probability of finding comparable or partly comparable discursive configurations which need not be mediated by direct influences.

Starting from these most elementary findings, there remains the task of describing in detail the formal entity ("work") to which this material is synthesized in both cases. At this point, a more elaborate version of the ideas I am presenting here would have to address the question of how to account for the incontestable differences which always exist between two different works, even in the case of far-reaching commonalities. ${ }^{58}$ For the time being, I will leave it at saying that, within the framework suggested by me, such differences are conceptualized as being based to a much greater extent on external factors than in the common view informed by categories like "creativity" or "ingenuity". The ending Calderón constructs for his version of a conflict that is not that different from the one to be found in Hamlet is most likely not primarily contingent on the author's personal choice or genius, but rather on what I am calling demand and control. The concept of definitive failure does not have its place within the worldview of Counter-Reformation Catholicism. It is not without reason that the generic term for Spanish Baroque drama is comedia; the meaning of the term is similar to the one intended by Dante when he named his great poem the Divine Comedy. And I should like to add that the fact that Shakespeare, rather than Calderón, is considered a timeless genius from the nineteenth century through the present might be less due to the intrinsic qualities of his texts, hence, to his personal creativity, than to the course that, for reasons we are hardly able to discuss within the field of literary studies proper, general and intellectual history has taken from the eighteenth century onward-a course which favours the ongoing extraction of Shakespeare's dramas from the cultural net, while disadvantaging Calderón's comedias in this respect.

ism; in any case, the world-model conveyed by (serious) Skakespearean dramas has affinities to the pattern of tragedy. The oedipal configuration is thus "assembled" into a different basic template than in the case of Calderón's play.

58 -unless we are dealing with epigonic texts. 
A network theory of cultural production becomes, however, intriguing once one is prepared to go beyond the frame of a two-text comparison, as is standard in the discipline. One need not transgress the generic boundaries of the phenomena scrutinized in order to integrate the works of the second author of worldliterary stature of that age, Cervantes, into the scenario. ${ }^{59}$ It would be tempting to say a few words about the Quijote (1605/1615). But within this context, it may even be more illuminating to stay with the genre of drama. The play in question bears the title of Entremés del retablo de las maravillas (1615). ${ }^{60}$ The title is intentionally ambiguous. A "retablo" is, primarily, an altarpiece presenting religious paintings, including miracles-in Spanish: maravillas; ${ }^{61}$ in Golden Age usage, "retablo" might also refer to a stage where a show is performed. ${ }^{62}$

The plot of the piece might be summarized as follows: a troupe of wandering actors enters a village, sets up its stage (the retablo), and then performs various short scenes; one is thus dealing with a play within the play. The only link between these scenes is their sensational content: the biblical Samson tearing

59 For a detailed analysis, see Leonie Pawlita, Skeptizismus im europäischen Drama der Frühen Neuzeit. Untersuchungen zu Dramentexten von Shakespeare, Calderón, Lope de Vega, Rotrou und Cervantes, Berlin 2015.

60 Entremés is a generic term. The French equivalent, farce, also used in English and German, may be more familiar, the literal meaning of the two terms being exactly the same: something that is put in between two other items. The original field of application of the French term is the culinary sphere; it designates a mixture of meat and spices put into a bigger piece of meat, mostly poultry, in order to enhance the taste of the entire roast. In the case of drama, these further items are acts of a serious drama, often with a didactic-in that age: religious-content. In the High Middle Ages, such didactic plays (Nativity and Passion plays, referring to biblical history, or morality plays, presenting allegories of virtues and vices fighting against each other) attained a length which made representations last for more than one or two days. In order to provide some relief from these huge quantities of doctrinal or moralizing profile, dramatists started creating short intermediate one-act plays (entremeses or farces) whose action was independent from the main play and whose content was meant to be entertaining, that is, at least comic, and in many cases also obscene. The reaction of the contemporary audience to these interludes seems to have been so positive that, as early as from the thirteenth century onward, they developed into independent plays typically performed by itinerant troupes on occasions such as fairs. High canon comedy, such as that of the French author Molière, owes much to this tradition of farce, which was productive up to the end of the fifteenth century. As to the function of these plays, as well as their development into independent plays, the theory of the carnivalesque by Mikhail M. Bakhtin provides all necessary details (Rabelais and His World, Hélène Iswolsky [tr.], Bloomington, IN 1984).

61 Frequent subjects were for instance Christ's Ascension or the descent of the Holy Spirit on Pentecost (etc.).

62 I shall come back to the intentional ambiguity of the term in a later passage of the present study. 
down the columns of a temple dedicated to an idol; a huge number of mice appearing on the stage and scaring in particular the female contingent of the audience; wild and dangerous beasts-such as bears and lions, or a bull who is said to have killed a man in Salamanca-running around on stage (etc.). Actually, however, there is nothing to be seen on the stage. The actors behave and talk to each other as if the scenes mentioned were being performed, and the villagers enthusiastically agree, to the point of being seized by fear when the lions are allegedly prowling around the stage. The reason for their readiness to accept the actors' pretentions as true is conveyed in a scene taking place before the (non-)performances within the performance: the stage director tells the villagers that the contraption set up is named "the stage of miracles" because only people of legitimate birth (stemming from a couple who is united by the bond of sacramental marriage) and who are, in addition, so-called "old Christians" (cristianos viejos), that is, who are free from the suspicion of having Jewish ancestors, would be able to perceive what is presented onstage.-The striking peculiarity of the Cervantian functionalization of a well-known motif is encoded in the ending. A quartermaster of the royal army suddenly appears. He announces that there are some dozen military men to be hosted, and asks the villagers to make the necessary preparations. These, however, or the bigger part of them, believe the quartermaster to be part of the stage action. They ask the stage director to present more entertaining scenes, and start hitting the quartermaster, as the latter does not show any readiness to leave the "stage". The military man reacts accordingly: he draws his sword and stabs a great number of the villagers. ${ }^{63}$ The play thus ends in a bloody disaster.

The skeptical tenor of the entire construction is provided by the fact that the villagers really believe to be seeing what is only recounted to them: sensory perception might be biased by ideological commitments or societal constraints. Yet quite like La vida es sueño and Hamlet, the Cervantian entremés is not content to reassert the basic tenets of skepticism. The breach of generic conventions practiced by Cervantes, the mix of comedy and disaster, lays bare the impasse into which skepticism leads in an even more drastic way than the plays of Calderón and Shakespeare. The general tendency of the plays, however, is analogous, and it may be characterized as follows: The assumptions of skepticism may be irrefutable. There are quite a number of various factors which may bias sensory perceptions in such a way that perceiving humans are

63 In those times, hosting military men from one's own country on their demand was, indeed, a legal obligation. If there was resistance to this law, the soldiers were entitled to take by physical force what was not conceded voluntarily. 
not able to decide what is "real" and what is only an illusion produced by the potentially fallacious interaction between their sensory apparatuses and their minds. But human life is full of situations in which serene isosthenia and ataraxia are not a convincing answer to the problems raised by the skeptics' hypotheses. Especially when it comes to questions of life and death, there is a difference between a sword that is merely perceived and a sword that is both perceived and real. The former one may cause fear; the latter may cause fear, but it may in addition kill.-Like the other dramatists, Cervantes does not have an epistemological answer to the problem he stages in his entremés. But it may be that the final unacceptability of the skeptical positions for humans who want to survive, presented by the dramatists, paved the way for the either provisional or logically problematic solutions to the question, as devised in contemporary philosophical discourses, to become acceptable. ${ }^{64}$

There are similar dramatic texts in other European countries of that age, in particular in France. ${ }^{65}$ The main difference between the processes to be observed in Spain and England on the one hand and France on the other consists in the fact that, within the latter context, the skeptical material was also direct-

64 With the above remark, I am referring to empiricism on the one hand (Bacon) and rationalism (Descartes) on the other. Empiricism programmatically rejects the attempts at finding out the "true nature" of the phenomena and limits the results of human conceptualization to the status of provisional framings, liable to be revised as soon as a new item pertaining to the phenomenon in question is detected. Descartes's attempt at constructing a reliable conceptualization of the world by grounding it in some basic "innate" rational concepts is contingent upon the assumption that there is a God who is not a deceiver (a genius malignus); at closer scrutiny, it thus turns out that Descartes's alleged establishment of autonomous reason goes on being linked to religious belief-not to concrete dogmas, but to the idea of a benevolent creator and prime mover (see my "La vida es sueño. 'Aufhebung' des Skeptizismus, Recusatio der Moderne”, in: Friedrich Wolfzettel and Joachim Küpper [eds.], Diskurse des Barock: Dezentrierte oder rezentrierte Welt?, München 2000, pp. 383-428).

65 One might think of Rotrou's Le véritable Saint Genest (1647), directly inspired by Lope de Vega's Lo fingido verdadero (1609); yet as "all-too Spanish" and all-too unoriginal, the play was only of minor importance in contemporary France.-In addition, there is a host of further plays in French, not only comedies, but also "tragi-comédies", in which the potentially fallacious character of sensory impressions constitutes an element of the intrigue. In the first place, one would have to mention Corneille's L'Illusion comique (1636), a play that shares, as may be said in passing, quite a few elements with similar plays by Calderón, such as El mágico prodigioso (1637) or En esta vida, todo es verdad y todo mentira (1659). My above differentiation of the situation in France from England and Spain might become more plausible if one takes into consideration the relative weight of the plays in question within their respective contexts. Amongst all of the plays written by Shakespeare as well as those by Calderón, the two mentioned are considered outstanding. As to Corneille's oeuvre in its entirety, L'Illusion comique is regarded as rather marginal. 
ly assembled into an abstract epistemological frame, namely in Descartes's Meditations (ca. 1650). ${ }^{66}$ In the text's first section, the philosopher refers almost verbatim to the famous fourth trope of Sextus Empiricus, also present in Calderón's play, which illustrates the unreliability of sensory perception by drawing attention to the fact that subjective impressions concerning the world that arise while humans are awake may be undistinguishable from those that arise during sleep. In contrast to the two playwrights, Descartes finally does present a solution to the problem: namely, to scrutinize the data collected by the senses in the light of certain basic mathematical concepts.

Whether or not Descartes's solution to the problem that is at the center of the three dramas as well is tenable or not shall not be discussed at this point. The mere fact that a question of high discursive importance was extracted from the cultural net with a view to assembling it in the frame of drama on the one hand and in an epistemological frame on the other, is quite remarkable, and one might derive from this observation a hypothesis which may seem at first glance daring: seventeenth-century France may have chosen a path that differs from England and Spain with regard to culture. Mass media phenomena are confined to the field of a highly sophisticated comedy which takes up serious problems, but always under the imperative limitation to entertainment. Thus, high culture and low culture remain separate, or rather remain much more separate than in other countries during that age. "Serious" themes are discussed in tragedies whose representations were not accessible to the common people, but only to a social elite (la cour et la ville $e^{67}$ ). But even tragedy is, within the strictly hierarchical French cultural pattern of that period, only a relatively low level of organizing cultural material. The relevant level is that of philosophical texts which do not exist stricto sensu in Spain and England in that age, where they either are confined to epistemology ${ }^{68}$ or are "scholastic", that is, unoriginal in content. ${ }^{69}$ Early modern France produces social cohesion by a means which

66 For the striking parallels, down to specific formulations, regarding the reliability of sensory perception in La vida es sueño and the Meditations, see the essay quoted in n. 64; as to a possible explanation within the frame of my theoretical approach, see below, pp. 115-134, esp. pp. $118 \mathrm{f}$. and pp. $126 \mathrm{f}$.

67 For a description of the social configuration apostrophized in this formula, see the famous essay by Erich Auerbach, in: E. A., Scenes from the Drama of European Literature, Ralph Manheim (tr.), Manchester 1984, pp. 133-182.

68 The most important example would be Francis Bacon's Novum organum scientiarum (1620). 69 It might seem inadequate to qualify all of scholastic philosophizing, including the texts of Francisco Sanches and Francisco Suárez, as lacking originality. But one has to put the contribution they made to the philosophical discourse of that time in perspective. Compared to the anti-scholastic revolution as theorized by Descartes, implying the rejection of authority and tradition as a source of truth, seventeenth-century scholasticism is not as yet as "exhausted" 
also exists in the two other countries, but at a much lower degree of societal relevance: the imaginary identification of the people with the State symbolized by the monarch. ${ }^{70}$ The stage of seventeenth-century France is not the stage, it is the court, which, however, is not directly accessible to the people in terms of perception. ${ }^{71}$ In early modern French culture, there is a relatively strict separation between the discursive sphere and the sphere of the imaginary. ${ }^{72}$ It remains to be discussed how such "national" exceptions may be accounted for within the frame of a network theory of cultural production, on the basis of which it would be in principle questionable for there to be such "national" circuits.-The configuration outlined above may suffice as a first, provisional example of what a network theory of cultural production may be able to yield.

5.-As to methodology, it needs to be emphasized that the problems discussed within this book were investigated at two different levels of generality. The research group working on the question produced a variety of books, major articles, and conference proceedings, all of which deal with specific configurations within the framework outlined above. ${ }^{73}$ The present book tries to systematize the findings of the various investigations and to synthesize the insights

a paradigm as it will be in the eighteenth century; but in terms of intellectual history, it is a framework on the verge of obsolescence.

70 The distinctive feature of French absolutism in that age is stability. In England, stability was contravened by dynastic controversies, combined with religious schisms and clashes. In Spain-Europe's first absolutist state-it was drastic economic instability, caused by a premodern, essentialist theory of money and value, which made the monarchy more and more into a problematic institution, or at any rate, into a power which was in no way apt to serve as a focal point for imaginary societal identification.

71 It was roughly one hundred years later when the reverse side of this configuration produced political effects of world-historical impact. The complete and strict separation of court and populace allowed for the spreading of rumors regarding the life at court which provoked the people to scrutinize things themselves. From the moment the fishwives forced King Louis XVI to "accompany" them from Versailles to the city, the chance to preserve the traditional system and to protect it against being revolutionized vanished.

72 The long-lasting impact of this separation can still be observed today. At least up to the end of the twentieth century, and perhaps even into the twenty-first century, mass media culture, although existent, is of lesser importance in France than in countries like Britain, Spain, or Germany.

73 In cases where the monographs are published or will be published at about the same time as this book, I shall only quote these titles, although chapters of the books in question may have appeared or may appear in the proceedings of the five conferences the DramaNet research group convened, or in reviews. In cases where the book publications will need some more time before becoming accessible to possible readers, I shall add titles of articles related to the book in question which have been published or will be published at around the same time as this book. 
gained there by further developing the theory of culture as a virtual network. At the same time, it provides an attempt at integrating the historically specific panorama of texts which was at the center of all specific investigations by presenting the thesis of contemporary theater as an early modern mass media culture.-The "mapping" of the field researched implies that this book will consistently refer to specific cases and configurations, but in a concentrated fashion. Readers longing for more philological substantiation are invited to take a look at the books and articles originating from the various subprojects and conference proceedings. This said, the present study and its theses are written with the intention of being self-explanatory; referring to the other publications produced by the research group is thus meant to be a possibility, but not a necessity.

In order to provide orientation regarding the entire field which was taken into consideration, I will briefly give some basic information concerning the various specific investigations that constitute the, so to speak, material basis of the theses and assumptions developed in the present book.

According to the above-mentioned fact that it is primarily the traditional concept of "national literatures" which is contested by the DramaNet research group's approach, there is a range of investigations targeting the question of a circulation of literary and cultural material beyond linguistic borders and the insights that might be gained from a careful observation of the phenomena in question.

Post-medieval drama first emerged in Italy. Italian drama and theater of the early sixteenth century "floated" to all the other major dramatic cultures of the time. The question as to why there is no or only scarce "floating back" of the transformed material to Italy has been raised in terms of historical description $^{74}$ as well as in terms of theory. ${ }^{75}$-English and Spanish early modern dra$\mathrm{ma}^{76}$ stand in a most interesting configuration in that age with regard to the particular and the larger implications of the material investigated, as both rely on the "infrastructure" of public theater. The questions emerging from this configuration concern the point of whether there is anything reasonable to be predicated with respect to "origin", or whether one is bound to the thesis that

74 See specifically Katja Gvozdeva, Compagnie d'hommes joyeux. Performances carnavalesques (rite, jeu, théâtre) et culture académique en Italie et en France au seizième siècle.

75 See below, pp. $231 \mathrm{f}$.

76 See Pawlita, Skeptizismus im europäischen Drama der Frühen Neuzeit, and Jan Mosch, Moral Agency and Heteronomy in Shakespearean and Racinian Tragedy; see also Madeline Rüegg, The 'Patient Griselda' Myth in Late Medieval and Early Modern Literature. 
"new" cultural forms and patterns are contingent agglomerations of heterogeneous material available in the net. Whether there was "influence" or not, it is striking that both nations developed mass media infrastructures at the same time. Both are imperial powers in the period concerned, one of them, however, on the rise, the other in rapid decline. ${ }^{77}$-French drama of the period is peculiarly pertinent with regard to the theoretical frame here suggested in that it did not adopt the formal patterns of early modern drama developed in England and Spain in order to "fill”" it with its "own" contents, as, for example, German Protestant drama did with respect to Jesuit drama. The question to be discussed is that of possible reasons for this exception. Nevertheless, France partakes in the contemporary cultural net. As to material, both content as well as formal or poetological concepts, there is hardly anything original to be found in seventeenth-century French theatrical culture. ${ }^{78}$ The overall cultural configuration, however, is different. This may lead to the hypothesis that (early modern) France may constitute an alternative model of culture and society with respect to the rest of Europe.-German drama of the period ${ }^{79}$ is of interest for a network theory of culture in that it shares with Spanish drama of the time the denominator of being heavily informed by a logic of control based on religion. In addition, cultural transfer in both directions is intense; it is facilitated by political and dynastic configurations (the house of Habsburg). The great difference consists in that there are conflicting logics of religious control in German early modern theater (Protestant vs. Catholic), whereas Spain knows an ideological homogeneity brought about by the Inquisition as the first bureaucratic cultural control agency in human history. Notwithstanding this difference, the general intention behind the writing of dramas and their representation on stage was identical in both countries: it was to produce mental habits.-It is a remarkable phenomenon with regard to the reception of drama of the sixteenth and seventeenth centuries, at that time but also in later periods, that it operates right from the beginning beyond the boundaries of the "national" communities from which the texts originated. As to the period concerned, there is, amongst other cases, the spectacular Europe-wide reception of a drama as difficult to read as the Celestina $;^{80}$ as to phenomena at the same

77 See also the articles in the collective volume Theatre Cultures within Globalising Empires (Küpper et al. [eds.]).

78 See Mosch, Moral Agency and Heteronomy in Shakespearean and Racinian Tragedy.

79 See Toni Bernhart, Volksschauspiele. Dimensionen einer Gattung.

80 See Sven-Thorsten Kilian, "Escrituras andantes": Concepts of Text and Scripture in Early Modern Drama; by "reading" I mean in this context the reception on the conceptual level; the difficulty is not linked to the text's original language; it is thus preserved in the many translations which were produced and circulated all over Europe. 
time trans-"national" and trans-temporal, there is the German reception of Shakespearean and of Spanish Golden Age drama in the age of Romanticism, ${ }^{81}$ and the French reception of Shakespearean drama in that same age. The most intriguing point may consist in that these phenomena of cultural "importation" are to be observed particularly in an age of rising nationalism. At first sight, the configuration may be considered to be linked to the specific ingenuity of this specific author, Shakespeare. But there is a parallel to this paradoxical configuration, largely neglected by research so far, which is the reception of French and English drama, mediated by its previous reception in Germanspeaking principalities, at the eighteenth-century Russian court, and the ensuing emergence of dramatic production in Russian, which was one main component in the construction of a specifically Russian "identity". ${ }^{2}$-The corresponding phenomena in their entirety constitute a feature of cultural dynamics which impressively contests the nationalistic assumptions regarding culture that were officially prevalent in that period in all countries concerned.

There is one investigation dealing with the floating of cultural material across a border considered in traditional conceptualization as even more basic or "essential" than language, namely a border between civilizations which did not entertain relations of intense exchange for the larger part of their history. The problems for a network theory of cultural production emerging from such a configuration were dealt with by studying the "floating" of early modern European drama to colonial India, and the long-lasting effects this floating produced with regard to the emergence of "autochthonous" theater production (meaning: in Indian vernaculars), but also with regard to larger societal, even political developments observable in the second half of the nineteenth century. ${ }^{83}$-The intricate question of dominance and cultural imperialism, which cannot be avoided within a theory postulating a universal cultural net, has also been scrutinized with regard to the cultural activities of so-called "smaller" nations (littératures mineures, to use a term that has become current in recent years), namely, by analyzing the dramatic production of a small Slavic

81 Regarding Shakespeare, see Günther Erken, "Die Rezeption Shakespeares in Literatur und Kultur. Deutschland”, in: Shakespeare-Handbuch, Ina Schabert (ed.), Stuttgart 2009 (5 $5^{\text {th }}$ print), pp. 627-651; the seminal publication as to the reception of Calderón's dramas in Germany is Swana L. Hardy, Goethe, Calderón und die romantische Theorie des Dramas, Heidelberg 1965.

82 See Kirill Ospovat, Terror and Pity: Aleksandr Sumarokov and the Theater of Power in Elizabethan Russia, Boston, MA 2016.

83 See Gautam Chakrabarti, Familiarising the Exotic: Introducing European Drama in Early Modern India, Berlin 2016. 
country, one, however, that borders on the West: Slovenia. ${ }^{84}$ There is another such littérature mineure study focussing on popular drama (Volkstheater) written in a German dialect-hardly accessible to speakers of standard Germanas utilized in remote villages in the valleys of the Alps, in Tyrol. ${ }^{85}$ It is mainly these two investigations which yield the basis for a critical discussion of what is, in terms of theory, the antagonist of the line of argument developed in this book, namely, the concept of "national literatures" as first developed in Johann Gottfried Herder's theorizing of culture as essentially Volkskultur-specific works being linked organically to the specific tribes amongst whom they emerged-which was widely accepted in all European countries in the age of Romanticism and seems to be the more or less unconscious basis of literary studies, including postcolonialism, up to the present era.

The above-mentioned comparative studies scrutinize the problem of how to account for the relevance of "borders" within a frame assuming that the production of culture takes place within a universal (virtual) net by taking into consideration mainly dramatic texts. In addition, there is a number of more focused studies foregrounding a particular compound of material and its circulation in the net. One of these more specific studies targets a motif tradition from which a genre originated, the pastoral, ${ }^{86}$ which is highly interesting for the general frame at issue here, as it was "extracted" from the net with high frequency all over Europe for a certain period in early modern times, but stopped being reactivated in modernity proper.-Another such study discusses the relation between astrology and astronomy in dramatic texts of the age, and thus opens up questions concerning the multitude of discourses floating in the cultural net, including discourses of scientific profile, and their interaction. ${ }^{87}$ A third such focused investigation deals with the role and function of institutions or concepts of institutions enabling the circulation of the material in the net, its subsequent withdrawal, and its reassembly, in this case the concept of "academies". ${ }^{8}$-A fourth study scrutinizes the extent to which cultural practic-

84 See Jaša Drnovšek, “Certa Mina Dant VICtorIas”. Die Prozessionsspiele der Gegenreformation zwischen Politik und Poetik.

85 See Bernhart, Volksschauspiele.

86 See Pauline Beaucé, Parodies d'opéra au siècle des Lumières. Evolution d'un genre comique, Rennes 2013.

87 See Sabine Kalff, "Sterne auf der Bühne. Astronomie und Astrologie im Drama des 17. und 18. Jahrhunderts”, Comparatio vol. 8/2016, pp. 35-58.

88 See Stephanie Bung, "Playful Institutions. Social and Textual Practices in Spanish Academies”, in: Toni Bernhart, Jaša Drnovšek, Sven Torsten Kilian, Joachim Küpper and Jan Mosch (eds.), Poetics and Politics: Net Structures and Agencies in Early Modern Europe, Berlin and Boston, MA 2018. 
es received as performance and "real life" (cultural) practices might interact in order to implement behavioural patterns considered mandatory within a specific societal frame. ${ }^{89}$

Finally, there is a variety of investigations addressing the question of how to deal with specific configurations that may, in one way or other, cast a doubt on the basic assumptions implied by a network theory of cultural production. One such study is dedicated to what at first sight appears to be a most traditional investigation of motif or reception history; it deals with the story narrated in the last novella-the tale of Griselda-from Boccaccio's Decameron (1351) and its "floating" to almost all major and minor European dramatic cultures in the early modern age. ${ }^{90}$ This study is of particular importance, as it allows for the assessment of what exactly differentiates the theoretical approach here suggested from more conventional approaches to literary history.-There is an investigation dealing with the floating of cultural material that has to be assigned to a meta-level, namely, the question of the extent to which it may be productive to theorize the transculturation of aesthetic concepts within the framework here submitted, that is, concepts assessed as being of a general, transnational profile even in traditional literary and cultural theory. ${ }^{91}$-Finally, there is a study which follows a line of thought that may be considered an alternative to the one here pursued. Starting from Hans Blumenberg's posthumously published deliberations on anthropology, ${ }^{92}$ it discusses the question of whether or not the assumption of transfer is necessary when it comes to observing certain commonalities between (literary) texts from different times and places, or whether such parallel structures may more sensibly be accounted for by hypothesizing that there are universal anthropological constants. ${ }^{93}$

This range of concrete phenomena might allow for a substantive, though not as yet definitive specification of the theoretical assumptions which shall be expounded in Part I of this book.

89 See, once again, Gvozdeva, Compagnie d'hommes joyeux.

90 See Rüegg, The 'Patient Griselda' Myth in Late Medieval and Early Modern Literature.

91 See Tatiana Korneeva, The Dramaturgy of the Spectator: Theatre, Audience, and the Public Sphere in Late Seventeenth- and Eighteenth-Century Italy.

92 See Hans Blumenberg, Beschreibung des Menschen, Berlin 2014.

93 See D. S. Mayfield, The Vicarious: Variants in Blumenberg. Delegation in Early Modern Drama (Rojas, Machiavelli, Shakespeare). 